\title{
Activation of a Metabotropic Glutamate Receptor Increases Intracellular Calcium Concentrations in Neurons of the Avian Cochlear Nucleus
}

\author{
Lance Zirpel, ${ }^{1,2}$ Edward A. Lachica, ${ }^{2}$ and Edwin W Rubel ${ }^{1,2}$ \\ 'Department of Physiology and Biophysics, SJ-40, School of Medicine, and ${ }^{2}$ Virginia Merrill Bloedel Hearing Research \\ Center, University of Washington, Seattle, Washington 98195
}

\begin{abstract}
Metabotropic glutamate receptors have been shown to stimulate phosphatidylinositol metabolism, and subsequently liberate $\mathrm{Ca}^{2+}$ from intracellular stores, in a variety of tissue and cell types. We previously demonstrated that glutamate could stimulate phosphatidylinositol metabolism, generating inositol-1,4,5-trisphosphate $\left(\mathrm{IP}_{3}\right)$, in isolated cochlear nucleus tissue from the chick. Using the calcium indicator dye fura-2 and ratiometric fluorescent imaging, this study examined the ability of glutamate and its analogs to liberate $\mathrm{Ca}^{2+}$ from intracellular stores of neurons of the avian cochlear nucleus, and qualitatively characterized the pharmacological profile of such an action. In normal, $\mathrm{Ca}^{2+}$-containing medium, glutamate, kainate (KA), $\alpha$-amino-3-hydroxy-5methyl-isoxazole-4-propionate (AMPA), NMDA, quisqualate (QUIS), and ( \pm )-aminocyclopentane-trans-dicarboxylate (ACPD) elicited increases in intracellular calcium concentrations $\left(\left[\mathrm{Ca}^{2+}\right]\right)$ ). In the absence of external $\mathrm{Ca}^{2+}$, glutamate, quisqualate, and ACPD evoked increases in $\left[\mathrm{Ca}^{2+}\right]_{r}$ in normal medium, the ionotropic glutamate receptor antagonist 6-cyano-7-nitroquinoxaline-2,3-dione (CNOX) and the NMDA receptor antagonist 2-amino-5-phosphonovalerate (APV) attenuated but did not abolish the glutamate-evoked response and had no effect on the ACPD-evoked response. The putative metabotropic glutamate receptor antagonist 2-amino3-phosphonopropionate (AP3) was without effect on the glutamate- and ACPD-evoked increases in $\left[\mathrm{Ca}^{2+}\right]_{i}$ in $\mathrm{Ca}^{2+}$-free medium. We conclude that a metabotropic glutamate receptor (mGluR) is present on cochlear nucleus neurons and is able to stimulate the phosphatidylinositol metabolism-Ca ${ }^{2+}$ signal transduction cascade.
\end{abstract}

[Key words: deafferentation, auditory system, ACPD, nucleus magnocellularis, mGluR, excitatory amino acid]

Neurons in the embryonic and neonatal chick cochlear nucleus, nucleus magnocellularis (NM), are dependent upon eighth nerve input for maintenance of their metabolic activity and survival. Eliminating this input, either by cochlea ablation or perilym-

\footnotetext{
Received Apr. 25, 1994; revised June 10, 1994; accepted June 16, 1994.

This study was supported by NIH Grants GM07108 (L.Z.) and DC00395 (E.WR.) and the W. M. Keck Foundation. Thanks to Paulette Brunner for technical assistance, Mark Walter for help with the figures, and Drs. William Lippe and Neil M. Nathanson for helpful comments on the manuscript.

Correspondence should be addressed to Edwin W Rubel, Hearing Development Laboratory, RL-30, University of Washington, Seattle, WA 98195.

Copyright $\odot 1995$ Society for Neuroscience $0270-6474 / 95 / 150214-09 \$ 05.00 / 0$
}

phatic injection of TTX, results in the death of approximately $30 \%$ of the NM neurons (Born and Rubel, 1985; 1988). Within minutes to hours after the elimination of afferent activity, NM neurons display a variety of changes in their morphology and metabolic activity (reviewed in Rubel et al., 1990). Using an in vitro brainstem slice preparation, Hyson and Rubel (1989) showed that transneuronal regulation of one of these rapid metabolic changes, protein synthesis, requires calcium-dependent release of a "trophic substance" from the eighth nerve terminals. One candidate for this "trophic substance" is the neurotransmitter at the eighth nerve-NM synapse, the excitatory amino acid glutamate (Nemeth, Jackson and Parks, 1983; Jackson et al., 1985; Martin, 1985; Zhou and Parks, 1992a,b).

Glutamate receptors are categorized into two major groups; ionotropic and metabotropic. Ionotropic glutamate receptors (iGluRs) are linked to cation-conducting channels in the plasma membrane that mediate fast excitatory synaptic transmission and are classified, based on selective stimulation by agonists, into the following subtypes: (1) NMDA, (2) kainate (KA), and (3) $\alpha$-amino-3-hydroxy-5-methyl-isoxazole-4-propionate (AMPA) (Monaghan et al., 1989). Metabotropic glutamate receptors (mGluRs) are G-protein-linked receptors that regulate intracellular second messenger systems including phosphatidylinositol (PI) metabolism (Sugiyama et al., 1987) and adenylate cyclase activity (Cartmell et al., 1992; Schoepp et al., 1992; Winder and Conn, 1992). A family of mGluRs, designated mGluR 1-mGluR6, has been cloned and characterized based on pharmacological profile and second messenger activity (Houamed et al., 1991; Masu et al., 1991; Abe et al., 1992; Tanabe et al., 1992). mGluR 1 and mGluR5 are coupled to the phosphatidylinositol metabolism-intracellular $\mathrm{Ca}^{2+}$ signal transduction pathway and are potently stimulated by quisqualate, less potently by \pm -aminocyclopentane-1,3-trans-dicarboxylate (ACPD). mGluR2, mGluR3, mGluR4, and mGluR6 are all coupled to the adenylate cyclase-cAMP transduction cascade (Nakajima et al., 1993; Tanabe et al., 1993). Despite different potencies at the different mGluR subtypes, ACPD activates all six mGluRs (Nakajima ct al., 1993; Schoepp, 1993; Tanabe et al., 1993).

Since it is likely that transneuronal regulation of neuronal metabolism would require activation of a second messenger system, it is possible that activity-dependent release of glutamate from the eighth nerve terminal could regulate the metabolism of the postsynaptic NM neurons via activation of one or more mGluRs. We previously reported that glutamate stimulates an increase in PI metabolism in isolated NM tissue via an 
mGluR (Zirpel et al., 1994). The goal of the present set of experiments was to evaluate the ability of glutamate and its analogs to act at an mGluR to affect intracellular calcium concentrations of NM neurons in an in vitro slice preparation.

These results have been previously published in abstract form (Zirpel and Rubel, 1993).

\section{Materials and Methods}

Tissue preparation. Brainstem slices were prepared from White Leghorn chicken embryos and hatchlings aged $18 \mathrm{~d}$ to the day of hatching (E1 8P0). Hatching normally occurs on E21. Embryos were decapitated and a thick coronal section containing the entire brain stem was obtained using a razor blade. The tissue was dissected from the cranium and the cerebellum removed. The brainstem was then immersed in $4 \%$ agarose dissolved in artificial cerebrospinal fluid (ACSF). Once the agarose solidified, a square block containing the brain stem was cut out and affixed to a vibratome stage with cyanoacrylate glue. Coronal slices were cut at $300 \mu \mathrm{m}$.

Slices containing NM were then placed in oxygenated ACSF containing 5-10 $\mu \mathrm{M}$ concentration of the acetoxymethyl ester (AM) form of fura- $2,1.7 \%$ anhydrous dimethylsulfoxide (DMSO) and $0.03 \% \mathrm{Plu}$ ronic. Slices were incubated in this solution for $25-45 \mathrm{~min}$ at room temperature, placed in the imaging chamber and perfused with normal ACSF for 10-15 min before data acquisition was initiated. Data were acquired from only one slice per animal.

Fluorescence ratio imaging. Fura-2-loaded NM neurons were alternately excited with $340 \mathrm{~nm}$ and $380 \mathrm{~nm}$ wavelengths of light from a xenon source using a computer-controlled shutter and filter wheel (Sutter Instruments, Novato, CA). Excitation wavelengths were attenuated to $3 \%$ of the original intensity by passing through a 1.5 o.d. filter. Exposure time for each excitation wavelength was between 500 and $750 \mathrm{msec}$. Fmitted light was passed through a $40 \times$ fluor oil immersion lens (Nikon) attached to a Nikon Diaphot inverted microscope, through a $480 \mathrm{~nm}$ longpass barrier filter and collected by an intensified CCD (Hamamatsu, Japan). Paired 340/380 excitation images were acquired every $3 \mathrm{sec}$ using IMAGE-1/FLUOR software (Universal Imaging Corp., West Chester, PA). Data were obtained as the ratio of fluorescence from $340 \mathrm{~nm}$ excitation over fluorescence from $380 \mathrm{~nm}$ excitation (340/380). Within physiological ranges, this ratio is a direct, linear measurement of intracellular $\mathrm{Ca}^{2+}$ concentrations (Grynkiewicz et al., 1985).

Drug application. Brainstem slices containing NM were placed in a custom chamber fitted onto the stage of the microscope. The floor of the chamber was a $1 \mathrm{~mm}$ thick coverglass. The tissue was stabilized with a weighted, stainless steel net and continually bathed with ACSF at a rate of approximately $3 \mathrm{ml} / \mathrm{min}$. The gravity-fed perfusion port was placed approximately $1 \mathrm{~mm}$ above the tissue slice and the vacuumremoval port was located on the floor of the chamber at the greatest possible distance from the tissue. This configuration allowed for rapid and efficient drug delivery to and removal from the tissue. Slices were exposed to only one type of agonist in any given experiment. Agonists were usually applied for $60-90 \mathrm{sec}$. Occasionally, if an agonist did not elicit an immediate response, application was extended for up to $5 \mathrm{~min}$. This extended application never produced a response that was not observed within the first $60 \mathrm{sec}$. In $\mathrm{Ca}^{2+}$-free and NMDA experiments, slices were perfused with $\mathrm{Ca}^{2+}$ - or $\mathrm{Mg}^{2+}$-free $\mathrm{ACSF}$, respectively, for 2 min prior to agonist application.

Data analysis. Ratios of $340 / 380 \mathrm{~nm}$ excitation were plotted as a function of time using EXCEL (Microsoft, Redmond, WA), CRICKET GRAPH (Cricket Software, Malvern, PA), and IGOR (Wavemetrics, Lake Oswego, OR). Baseline ratio values were obtained by averaging ratios $30 \mathrm{sec}$ preceding agonist application. Peak response ratio values were obtained from anywhere within the first $90 \mathrm{sec}$ after initiating agonist application. Responses were then expressed as percentage change in $340 / 380$ ratios relative to baseline values. Two-tail $t$ tests and one factor analysis of variance were performed using STATView (Abacus Concepts, Berkeley, CA). Variation across experiments (i.e., slices) was not reliably grcatcr than variation between cells in a given slice; therefore, experimental data were combined. Values presented are means followed parenthetically by the standard error of the mean.

Fura-2 labeling was uniform throughout the cytoplasm with an occasional NM neuron displaying an intensely labeled nucleus. Glia were also labeled but are much smaller than NM neurons, are easily discernible, and therefore easy to exclude from the data acquisition process.
Terminals, or calyces, did not appear to be labeled. NM neurons were labeled throughout the depth of the slice and the intensity of fluorescence was inversely proportional to distance from the plane of focus. The plane of focus was adjusted to yield the largest number of intensely fluorescent NM neurons. Labeled NM neurons in a given slice were chosen for analysis if the $340 / 380$ ratio image was $>50$ adjacent pixels. An "average" slice typically had approximately eight labeled NM neurons fulfilling this criteria. Throughout an experiment, several NM neurons would be excluded from analysis for the following reasons: (1) bleaching (loss of fluorescence), (2) inability to recover from an agonist application, (3) spontaneous and irreversible increase in 340/380 ratio (presumably cell death), and (4) large, spontaneous shifts in baseline $340 / 380$ ratio (low signal-to-noise ratio). Therefore, though each slice had a number of labeled NM neurons, the quantitative results we report here were obtained from as few as one to as many as $18 \mathrm{NM}$ neurons in any one slice. The number of neurons from which statistics were calculated is presented, followed by $n=$ number of slices.

Drugs, chemicals, and media. ( \pm )-1-Aminocyclopentane-trans-1,3dicarboxylate ( \pm -ACPD) and $1 S, 3 R$-aminocyclopentane-trans-dicarboxylate $(1 S, 3 R$-ACPD) were acquired from Tocris Neuramin (Essex, UK) and Research Biochemicals Inc. (RBI) (Natick, MA). AMPA, CNQX, KA, and quisqualate were from RBI. APV was from Cambridge Research Biochemicals (Cambridge, UK). AP3, glutamate, and NMDA were from Sigma Chemical (St. Louis, MO). Anhydrous DMSO was from Aldrich Chemical Co. (Milwaukee, WI). Fura-2 was from Molecular Probes (Eugene, OR). All other chemicals were analytical grade.

All drugs were dissolved in ACSF with the exception of CNQX, which was dissolved in DMSO and diluted to working concentration with ACSF. KA and quisqualate were prepared from $1000 \times$ stock solutions, in distilled $\mathrm{H}_{2} \mathrm{O}$, that were stored at $-40^{\circ} \mathrm{C}$. All other solutions were prepared within $24 \mathrm{hr}$ of use. ACSF consisted of (in $\mathrm{mM}$ ) $\mathrm{NaCl}, 130$; $\mathrm{KCl}, 3 ; \mathrm{CaCl}_{2}, 2 ; \mathrm{MgCl}_{2}, 2 ; \mathrm{NaHCO}_{3}, 26 ; \mathrm{NaH}_{2} \mathrm{PO}_{4}, 1.25 ;$ and glucose 10. Calcium-free ACSF was obtained by replacing $\mathrm{CaCl}_{2}$ with $\mathrm{MgCl}_{2}$ and buffering with $1 \mathrm{~mm}$ EGTA. Magnesium-free ACSF was obtained by omitting $\mathrm{MgCl}_{2}$. ACSF solutions used to depolarize NM neurons contained $60 \mathrm{mM} \mathrm{KCl}$

\section{Results}

Approximately $90 \%$ of all fura-2-loaded NM neurons had baseline $340 / 380$ ratios between 0.3 and 1.5 . In several experiments in which the imaging system was calibrated (Grynkiewicz et al., 1985), these ratios corresponded to intracellular $\mathrm{Ca}^{2+}$ concentrations ranging from $50 \mathrm{~nm}$ to $150 \mathrm{~nm}$ (data not shown). Any cells with baseline ratios above 1.5 were not included in the analyses. All slices were initially depolarized with $60 \mathrm{~mm} \mathrm{KCl}$ to assess NM neuron viability. Healthy neurons should respond with a rapid and robust increase in $340 / 380$ ratio followed by a rapid return to prestimulus values. Cells that did not respond to the initial $\mathrm{KCL}$ application with at least a $100 \%$ increase in $340 / 380$ ratio were also excluded from analysis. Application of $60 \mathrm{mM} \mathrm{KCl}$ resulted in a rapid increase in 340/380 ratio of NM neurons (Figs. 1-3). The average 340/380 increase of $217 \mathrm{NM}$ neurons ( $\mathrm{n}=51$ slices) in response to $60 \mathrm{mM} \mathrm{KCl}$ depolarization was $288 \%( \pm 21)$. Recovery to baseline levels was not as rapid as the increase and appeared to be biphasic: a rapid decrease followed by a gradual return to prestimulus levels (see Figs. 13 ). On rare occasions, a response was observed that showed a rapid rise, but then plateaued or showed a much more gradual increase before returning to baseline. The response to $60 \mathrm{~mm}$ $\mathrm{KCl}$ in Figure $1 A$ is an example of this type of response. Cells that did not return to prestimulus baseline levels within $5 \mathrm{~min}$ of returning to normal ACSF were excluded from further analysis.

Tables 1-3 summarize responses of NM neurons to agonist applications. For these tables, we present data that are expressed as a percentage increase above baseline 340/380 ratios. All responses are significantly different from 0 at the $p<0.05$ level. 

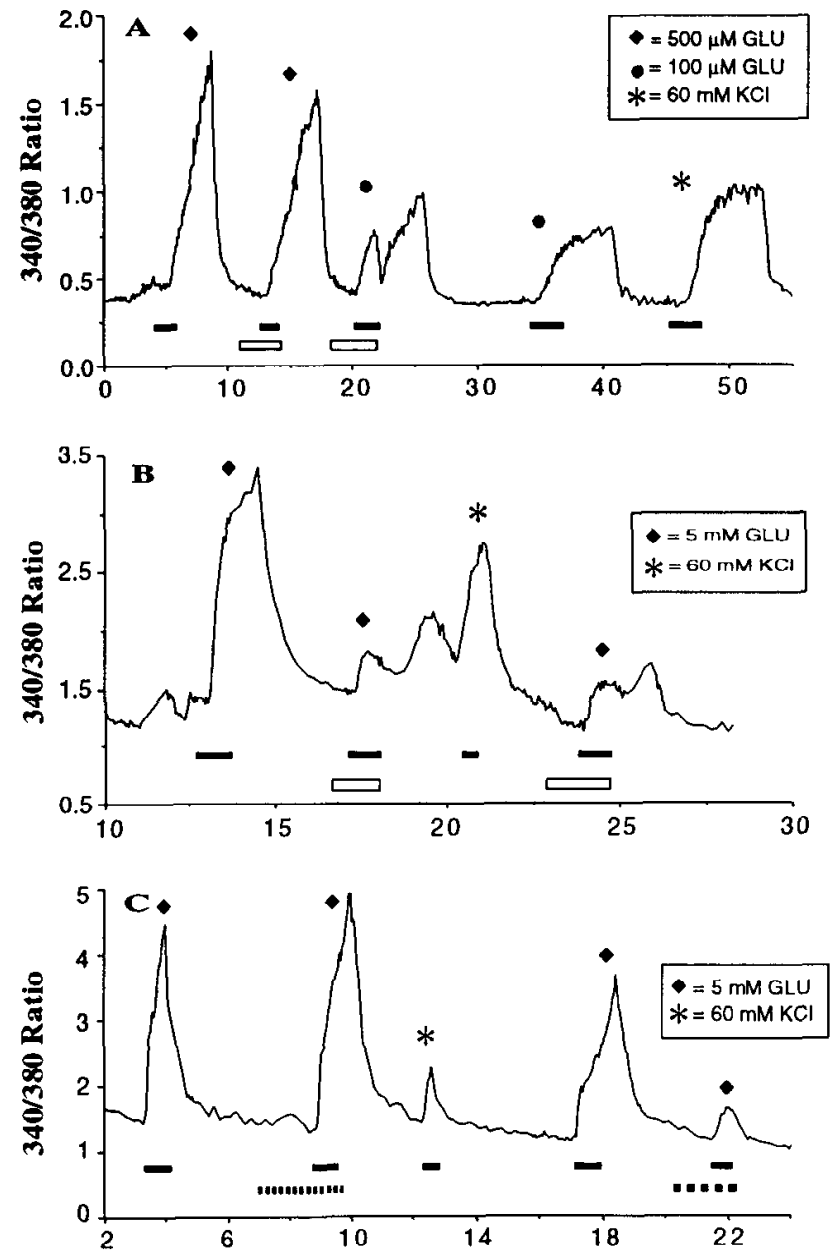

Time (minutes)

Figure $1 . \mathrm{Ca}^{2+}$ influx and mobilization from intracellular stores by glutamate. $A$, Trace from a single fura-2-labeled NM neuron responding to bath application of glutamate (GLU). Both 100 and $500 \mu \mathrm{M}$ GLU increased the $340 / 380$ ratio (i.e., intracellular calcium concentration, $\left.\left[\mathrm{Ca}^{2+}\right]_{i}\right)$ in normal and $\mathrm{Ca}^{2+}$-free ACSF. Solid bars beneath the trace indicate agonist application; open bars indicate application of $\mathrm{Ca}^{2+}$-free ACSF. The response of this neuron to $100 \mu \mathrm{M}$ GLU in $\mathrm{Ca}^{2+}$-free ACSF is an example of the "rebound" type of response: when returned to normal ACSF the 340/380 ratio rebounds to a level above that attained in $\mathrm{Ca}^{2+}$-free ACSF. The responses to $100 \mu \mathrm{M}$ GLU in normal ACSF and $60 \mathrm{~mm} \mathrm{KCl} \mathrm{show} \mathrm{a} \mathrm{plateau} \mathrm{effect} \mathrm{and} \mathrm{are} \mathrm{not} \mathrm{typical} \mathrm{responses.} B$, Trace from a single NM neuron showing that $5 \mathrm{mM}$ GLU elicits an increase in 340/380 ratio in both normal and $\mathrm{Ca}^{2+}$-free ACSF. Solid bars beneath the trace indicate agonist application; open bars indicate application of $\mathrm{Ca}^{2+}$-free ACSF. NM neurons responded to either millimolar or micromolar concentrations of GLU, but not both. See results for explanation. Note that both applications of GLU in $\mathrm{Ca}^{2+}$-free ACSF resulted in rebound responses. $C$, Trace from a single NM neuron showing that AP3 (1 mM) has no effect on the GLU-induced increase in 340/ 380 ratio while the combination of CNQX $(30 \mu \mathrm{M})$ and APV $(200 \mu \mathrm{M})$ attenuates, but does not abolish it. Solid bars indicate agonist application; narrow-hatched bar indicates application of $1 \mathrm{mM} \mathrm{AP3}$; widehatched bar indicates application of $30 \mu \mathrm{M}$ CNQX and $200 \mu \mathrm{M}$ APV. Note different axes values for each trace.

\section{Glutamate}

Fura-2-loaded NM neurons responded to bath-applied glutamate with an increase in the $340 / 380$ ratio, which corresponds to an increase in $\left[\mathrm{Ca}^{2+}\right]_{i}$. However, the NM neuron responses to glutamate fell into one of two mutually exclusive populations:
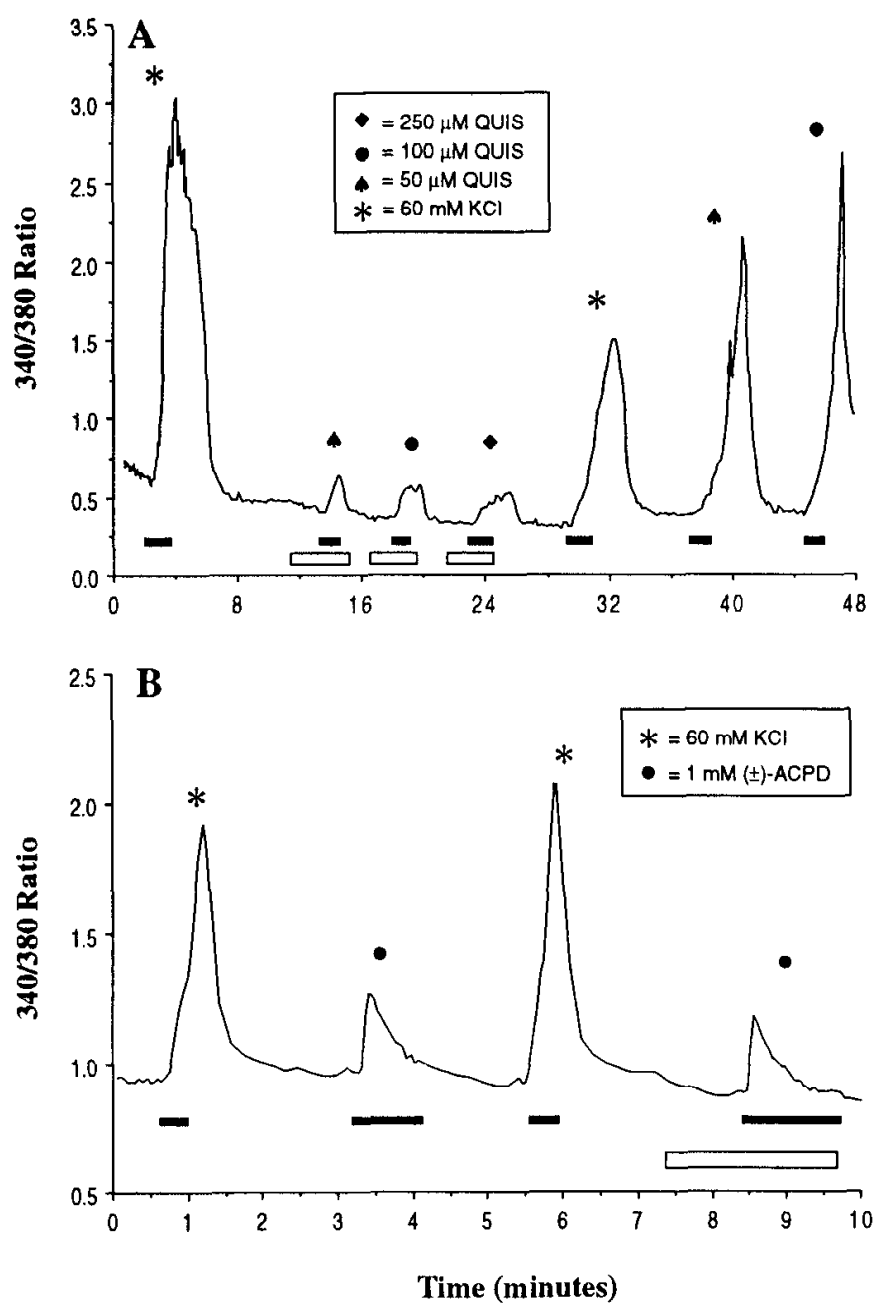

Figure 2. $\mathrm{Ca}^{2+}$ influx and mobilization from intracellular stores by quisqualate $(Q U I S)$ and $( \pm)$-ACPD. $A$, Trace from a single NM neuron showing that QUIS elicits an increase in 340/380 ratio in both normal and $\mathrm{Ca}^{2+}$-free ACSF. Solid bars beneath trace indicate agonist application; open bars indicate application of $\mathrm{Ca}^{2+}$-free ACSF. Concentrations of QUIS above $250 \mu \mathrm{M}$, in normal ACSF induced increases in the $340 / 380$ ratio from which the NM neurons could not recover. The observation that this neuron responded to three consecutive QUIS applications in $\mathrm{Ca}^{2+}$-free ACSF suggests that depolarization-loading of the intracellular stores is not necessary. $B$, Trace from a single NM neuron showing that ( \pm )-ACPD (1 mM) elicits a small 340/380 ratio increase in normal and $\mathrm{Ca}^{2+}$-free $\Lambda \mathrm{CSF}$. Solid bars beneath trace indicate agonist application; open bars indicate application of $\mathrm{Ca}^{2+}$-free ACSF. Lower concentrations (10-500 $\mu \mathrm{M})$ of ( \pm )-ACPD and $1 S, 3 R$-ACPD failed to elicit any change in 340/380 ratio in 33 applications to 72 NM neurons in nine slices. Note different axis values for each trace.

elicited by micromolar concentrations or elicited by millimolar concentrations. In $36 \%$ of the slices tested, NM neurons responded to concentrations of glutamate (GLU) ranging from $100 \mu \mathrm{M}$ to $500 \mu \mathrm{M}$ with increases in 340/380 ratios as shown in Table 1. Figure $1 A$ shows an example of this response to 500 and $100 \mu \mathrm{M}$ GLU. Similar to the response to $\mathrm{KCl}$ depolarization, the GLU-induced $340 / 380$ increase was rapid followed by an equally rapid and biphasic decay upon GLU removal. As with $\mathrm{KCl}$ depolarizations, GLU occasionally elicited a response that appeared to "plateau." The NM neuron response to $100 \mu \mathrm{M}$ GLU in Figure $1 A$ is an example of this type of response. Within this population of slices, millimolar concentrations of glutamate 

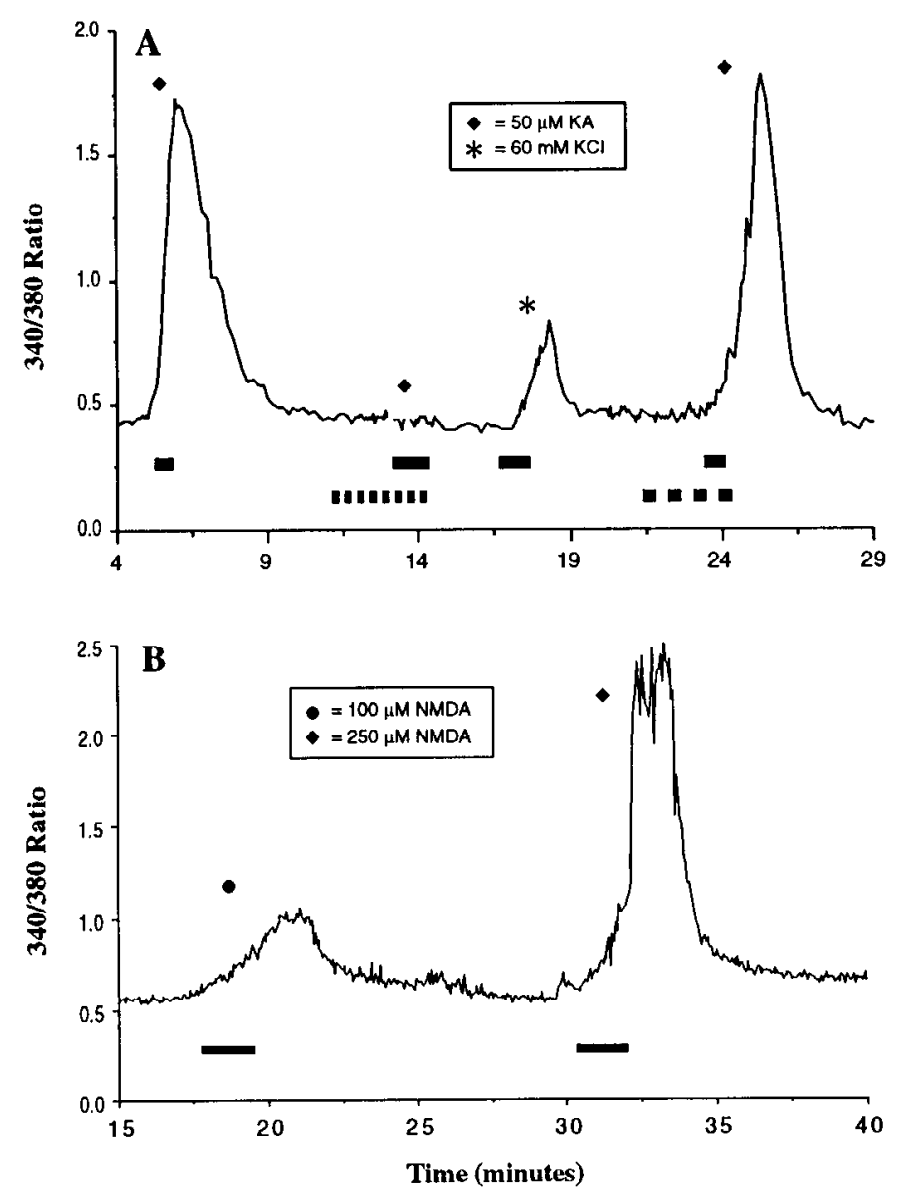

Figure 3. $\mathrm{Ca}^{2+}$ influx elicited by kainate (KA) and NMDA. $A$, Trace from a single NM neuron showing that $\mathrm{KA}(50 \mu \mathrm{M})$ elicits an increase in 340/380 ratio in normal ACSF. Solid bars indicate agonist application; narrow-hatched bar indicates application of $30 \mu \mathrm{M} \mathrm{CNQX}$ and 200 $\mu \mathrm{M}$ APV; wide-hatched bar indicates application of $1 \mathrm{~mm}$ AP3. This trace is typical of the NM neuron response to KA application. A combination of CNQX $(30 \mu \mathrm{M})$ and APV $(200 \mu \mathrm{M})$ completely abolishes the response to $\mathrm{KA}(50 \mu \mathrm{M})$. AP3 (1 mM) potentiates the response to KA $(50 \mu \mathrm{M})$. KA $(50 \mu \mathrm{M})$ failed to elicit any change in $340 / 380$ ratio in $\mathrm{Ca}^{2+}$. free ACSF in two applications to seven NM neurons in two slices. $B$, Single NM neuron trace showing that NMDA $(100$ and $250 \mu \mathrm{M})$ elicits an increase in $340 / 380$ ratio in normal $\mathrm{Ca}^{2+} / \mathrm{Mg}^{2+}$ free ACSF. Solid bars indicate agonist application. Four applications of NMDA $(500 \mu \mathrm{M})$ to $37 \mathrm{NM}$ neurons in five slices in $\mathrm{Ca}^{2+}$-free ACSF failed to elicit any change in the $340 / 380$ ratio. The response to $100 \mu \mathrm{M}$ NMDA in this trace is not typical as it shows a gradual $340 / 380$ increase without the fast spike-like increase that is more typical and evident in the response to $250 \mu \mathrm{M}$ NMDA. Note different axes values for each trace.

evoked increases in 340/380 ratios that saturated the imaging system and appeared to kill the NM neurons since they never recovered to basal $340 / 380$ ratios.

NM neurons of this population also responded to micromolar concentrations of glutamate with increases in 340/380 ratios in $\mathrm{Ca}^{2}$-free ACSF as listed in Table 1. Responses to GLU in $\mathrm{Ca}^{2+}$ free ACSF were slightly slower than the responses to GLU in normal ACSF. Surprisingly, the magnitude of responses in $\mathrm{Ca}^{2+}$ free ACSF was not significantly different from the magnitude of responses in normal ACSF. Figure $1 A$ also shows an example of this type of response to 100 and $500 \mu \mathrm{M} \mathrm{GLU}$ in $\mathrm{Ca}^{2+}$-free ACSF.

An interesting characteristic of the $\mathrm{Ca}^{2+}$-free responses was a "rebound" effect that occurred in approximately $30 \%$ of the
Table 1. Effects of glutamate and quisqualate on $340 / 380$ ratios of fura-2-labeled $N M$ neurons expressed as mean $( \pm$ SEM) percentage increase above basal ratios

\begin{tabular}{|c|c|c|c|c|}
\hline \multirow{2}{*}{$\begin{array}{l}\text { Concen- } \\
\text { tration } \\
(\mu \mathrm{M})\end{array}$} & \multicolumn{2}{|l|}{ Glutamate } & \multicolumn{2}{|c|}{ Quisqualate $^{a}$} \\
\hline & $\begin{array}{l}\text { Normal } \\
\text { ACSF }\end{array}$ & $0 \mathrm{Ca}^{2+} \mathrm{ACSF}$ & $\begin{array}{l}\text { Normal } \\
\text { ACSF }\end{array}$ & $0 \mathrm{Ca}^{2+} \mathrm{ACSF}$ \\
\hline 5 & $\begin{array}{l}\mathrm{NR} \\
(7, n=2)\end{array}$ & $\begin{array}{l}\text { NR } \\
(7, n=2)\end{array}$ & $\begin{array}{l}58( \pm 7) \\
(9, n=3)\end{array}$ & ND \\
\hline 10 & ND & ND & $\begin{array}{l}68( \pm 12) \\
(13, n=6)\end{array}$ & $\begin{array}{l}17(+2) \\
(15, n=3)\end{array}$ \\
\hline 20 & $\begin{array}{l}\text { NR } \\
(16, n=2)\end{array}$ & $\begin{array}{l}\text { NR } \\
(16, n=2)\end{array}$ & $\begin{array}{l}85( \pm 12) \\
(18, n=4)\end{array}$ & ND \\
\hline 30 & ND & ND & $\begin{array}{l}100( \pm 41) \\
(17, n=3)\end{array}$ & $\begin{array}{l}28( \pm 4) \\
(15, n=3)\end{array}$ \\
\hline 50 & $\begin{array}{l}\text { NR } \\
(13, n=3)\end{array}$ & $\begin{array}{l}\mathrm{NR} \\
(8, n=2)\end{array}$ & $\begin{array}{l}214( \pm 33) \\
(19, n=8)\end{array}$ & $\begin{array}{l}56( \pm 5) \\
(10, n=4)\end{array}$ \\
\hline 100 & $\begin{array}{l}75( \pm 14) \\
(9, n=4)\end{array}$ & $\begin{array}{l}90( \pm 22) \\
(12, n=3)\end{array}$ & $\begin{array}{l}271( \pm 49) \\
(14, n=4)\end{array}$ & $\begin{array}{l}42( \pm 4) \\
(6, n=3)\end{array}$ \\
\hline 250 & $\begin{array}{l}80( \pm 19)^{b} \\
(15, n=3)\end{array}$ & $\begin{array}{l}80( \pm 21) \\
(15, n=4)\end{array}$ & $\begin{array}{l}-c \\
(13, n=3)\end{array}$ & $\begin{array}{l}54( \pm 6) \\
(15, n=4)\end{array}$ \\
\hline 500 & $\begin{array}{l}162( \pm 30) \\
(13, n=4)\end{array}$ & $\begin{array}{l}135( \pm 49)^{b} \\
(8, n=3)\end{array}$ & $\begin{array}{l}\overline{-}^{c} \\
(9, n=2)\end{array}$ & ND \\
\hline
\end{tabular}

The data in parentheses indicate the number of NM neurons and $n=$ number of slices. All responses are significantly different from zero at the $p<0.001$ level except where otherwise indicated. NR, No response; ND, no data.

all QUIS responses; $p<0.0001$.

" $p<0.05$.

Cclls did not rccover.

applications of GLU. Upon returning the slice to normal ACSF, following $\mathrm{Ca}^{2+}$-free GLU application, the 340/380 ratio dropped rapidly to a level above basal, but then increased rapidly to a level above that achieved in $\mathrm{Ca}^{2+}$-free ACSF. Return to baseline was then similar to that observed with the responses to $\mathrm{KCl}$ and GLU in normal ACSF. The third response peak in Figure $1 A$ is an example of this rebound effect. This type of rebound suggests the presence of a $\mathrm{Ca}^{2+}$-activated $\mathrm{Ca}^{2+}$ channel in the plasma membrane: as GIUU releases $\mathrm{Ca}^{2+}$ from intracellular stores, the rising $\left[\mathrm{Ca}^{2+}\right]_{i}$ activates the $\mathrm{Ca}^{2+}$-dependent channel, but there is no external $\mathrm{Ca}^{2+}$ to flow in; upon returning to normal external $\left[\mathrm{Ca}^{2+}\right]$ there is a rapid influx of $\mathrm{Ca}^{2+}$ through the stillactivated $\mathrm{Ca}^{2+}$-dependent channel.

In the remaining $64 \%$ of the slices tested, micromolar concentrations of GLU were ineffective at eliciting a 340/380 increase. However, NM neurons in these same slices responded to millimolar concentrations of GLU with an increase in 340 / 380 ratios as listed in Table 2 . Figure $1 B$ shows an example of this type of response to $5 \mathrm{~mm} \mathrm{GLU}$ in normal and $\mathrm{Ca}^{2+}$-free ACSF. The NM responses to millimolar concentrations of GLU were similar to the responses to micromolar concentrations in time course and shape. However, the responses to $5 \mathrm{~mm}$ GLU in $\mathrm{Ca}^{3+}$-frec ACSF were significantly smaller than the responses to $5 \mathrm{~mm}$ GLU in normal ACSF (Fisher's PLSD, $p<0.05$ ).

Since these two response populations were mutually exclusive (no slice was observed to respond, and recover, to both microand millimolar concentrations), the data were not combined nor compared quantitatively.

CNQX is an antagonist at the ionotropic KA and AMPA receptors and APV is a competitive antagonist at the NMDA receptor (Monaghan et al., 1989). AP3 is a putative antagonist 
Table 2. Effects of millimolar concentrations of glutamate and ( \pm -ACPD on 340/380 ratios of fura-2labeled NM neurons expressed as mean ( \pm SEM) percentage increase over baseline values

\begin{tabular}{|c|c|c|c|c|}
\hline \multirow{2}{*}{$\begin{array}{l}\text { Concentration } \\
(\mu \mathrm{M})\end{array}$} & \multicolumn{2}{|l|}{ Glutamate } & \multicolumn{2}{|l|}{$( \pm)-A C P D$} \\
\hline & Normal ACSF & $0 \mathrm{Ca}^{2+} \mathrm{ACSF}$ & Normal ACSF & $0 \mathrm{Ca}^{2+} \mathrm{ACSF}$ \\
\hline \multirow[t]{2}{*}{1000} & $64( \pm 10)^{a}$ & NR & $18( \pm 2)$ & $22( \pm 2)$ \\
\hline & $(15, n=3)$ & $(42, n=3)$ & $(49, n=6)$ & $(20, n=3)$ \\
\hline \multirow[t]{2}{*}{5000} & $271( \pm 28)$ & $57( \pm 7)$ & ND & ND \\
\hline & $(42, n=7)$ & $(19, n=4)$ & & \\
\hline \multirow[t]{2}{*}{$5000(1000)+1000 \mathrm{AP3}$} & $203( \pm 35)^{a}$ & $56(18)$ & ND & $21(\perp 3)$ \\
\hline & $(6, n=3)$ & $(16, n=3)$ & & $(14, n=3)$ \\
\hline \multirow{2}{*}{$\begin{array}{l}5000(1000)+30 \mathrm{CNQX} \\
\text { and } 200 \mathrm{APV}\end{array}$} & $173( \pm 22)$ & ND & $23( \pm 2)$ & ND \\
\hline & $(27, n=3)$ & & $(23, n=3)$ & \\
\hline
\end{tabular}

See Results for comparison of data in Table 1 versus these data. The data in parentheses indicate the number of NM neurons followed by $n=$ number of slices. Parenthetical numbers in the first column indicate ACPD concentrations. All responses are significantly different from zero at the $p=0.0001$ level unless otherwise indicated. ND, No data; NR, no response.

${ }^{a} p<0.005$

at several subtypes of mGluRs (Schoepp and Johnson, 1989; Houamed et al., 1991; Abe et al., 1992). The combination of CNQX $(30 \mu \mathrm{M})$ and APV $(200 \mu \mathrm{M})$ significantly (Fisher's PLSD, $p<0.05)$ attenuated the response to $5 \mathrm{~mm}$ GLU in normal ACSF, but did not abolish it (Fig. 1C). AP3 (1 mm) had no effect on the response evoked by $5 \mathrm{~mm}$ GLU in either normal (Fig. 1C) or $\mathrm{Ca}^{2+}$-free ACSF (Table 2).

\section{Quisqualate}

Quisqualate (QUIS) is a nonspecific glutamate receptor agonist and a potent activator of PI-metabolism-linked mGluRs (Monaghan et al., 1989; reviewed in Schoepp, 1993). Figure $2 A$ shows an example in which QUIS induced increases in the 340/380 ratio of a NM neuron in both normal and $\mathrm{Ca}^{2+}$-free ACSF. The

\begin{tabular}{|c|c|c|c|}
\hline Concentration $(\mu \mathbf{M})$ & Kainate & AMPA & NMDA \\
\hline 10 & $\begin{array}{l}52( \pm 3) \\
(9, n=3)\end{array}$ & $\begin{array}{l}114( \pm 33)^{a} \\
(19, n=3)\end{array}$ & ND \\
\hline 20 & $\begin{array}{l}189( \pm 40) \\
(19, n=6)\end{array}$ & $\begin{array}{l}181( \pm 37) \\
(14, n=3)\end{array}$ & ND \\
\hline 30 & $\begin{array}{l}490( \pm 136)^{a} \\
(12, n=3)\end{array}$ & $\begin{array}{l}257( \pm 37) \\
(31, n=4)\end{array}$ & ND \\
\hline 50 & $\begin{array}{l}286( \pm 23) \\
(21, n=5)\end{array}$ & $\begin{array}{l}211( \pm 34) \\
(14, n=4)\end{array}$ & $\begin{array}{l}\mathrm{NR} \\
(7, n=2)\end{array}$ \\
\hline $50+1000$ AP3 & $\begin{array}{l}721( \pm 163) \\
(12, n=3)\end{array}$ & ND & ND \\
\hline $\begin{array}{l}50+30 \mathrm{CNQX} \text { and } \\
200 \mathrm{APV}\end{array}$ & $\begin{array}{l}\text { NR } \\
(9, n=3)\end{array}$ & ND & ND \\
\hline 100 & $\begin{array}{l}\overline{-}^{c} \\
(7, n=2)\end{array}$ & $\begin{array}{l}-^{c} \\
(21, n=2)\end{array}$ & $\begin{array}{l}100( \pm 22)^{a} \\
(12, n=3)\end{array}$ \\
\hline 250 & $\begin{array}{l}\overline{(7}^{c} \\
(7, n=2)\end{array}$ & ND & $\begin{array}{l}238( \pm 81)^{b} \\
(15, n=3)\end{array}$ \\
\hline
\end{tabular}

Values expressed are mean $(+$ SEM) percentage increase from basal ratios. The data in parentheses indicate number of NM neurons and $n=$ number of slices. All responses are significantly different from zero at the $p<0.001$ level except where otherwise indicated. ND, No data; NR, no response.

a $p<0.005$.

" $p<0.05$.

c Cells did not recover. responses of NM neurons to various concentrations of QUIS in normal ACSF are listed in Table 1. Though not all concentrations are reliably different from one another, there is a significant effect of dose on the magnitude of response. Concentrations of QUIS higher than $100 \mu \mathrm{M}$ induced $340 / 380$ ratio increases from which the NM neurons could not recover (Table 1). QUISelicited responses were similar to GLU-elicited responses in time course and shape.

Like GLU, QUIS induced an increase in 340/380 ratio in $\mathrm{Ca}^{2+}$-free ACSF that was similar in shape to the responses in normal ACSF but was significantly (Fisher's PLSD, $p<0.05$ ) reduced in magnitude and had a slightly slower time course (Fig. $2 A$ ). Various concentrations of QUIS in $\mathrm{Ca}^{2+}$-free ACSF induced 340/380 ratio increases in NM neurons as listed in Table 1. There did not appear to be a significant effect of dose on the responses in $\mathrm{Ca}^{2+}$-free ACSF. Though not shown by the experiment represented in Figure $2 A$, approximately $30 \%$ of the NM neurons exposed to QUIS in $\mathrm{Ca}^{2+}$-free ACSF demonstrated the rebound effect described above. In most experiments, slices were depolarized with $\mathrm{KCl}$ between $\mathrm{Ca}^{2+}$-free agonist applications. It is interesting to note that this was not the case for the experimen $i$ represented in Figure $2 A$ (the slice was returned to normal ACSF between $\mathrm{Ca}^{2+}$-free QUIS applications) yet the NM neuron responded to subsequent $\mathrm{Ca}^{2+}$-free QUIS challenges with an increase in 340/380 ratio. This suggests that active "loading" of the intracellular stores is not required between responses.

\section{Aminocyclopentane-1,3-trans-dicarboxylate (ACPD)}

( \pm )-1-Aminocyclopentane-1,3-trans-dicarboxylate ( \pm -ACPD) is a specific agonist at all six subtypes of mGluRs (Nakajima et al., 1993; Schoepp, 1993; Tanabe et al., 1993) with little or no effect at the ionotropic glutamate receptors (Manzoni et al., 1990; Schoepp et al., 1991). The stereospecific enantiomer $1 S, 3 R$ aminocyclopentane-trans-dicarboxylate $(1 S, 3 R$-ACPD) appcars to bc the most potent form of this molecule (Irving et al., 1990; Schoepp et al., 1990). Concentrations from 10 to $500 \mu \mathrm{M}$ of either ( \pm )- or $1 S, 3 R$-ACPD failed to elicit any change in $340 /$ 380 ratio in $72 \mathrm{NM}$ neurons ( $n=9$ slices). However, Figure $2 B$ shows that $( \pm)$-ACPD (1 mM) elicited a small increase in 340/ 380 ratio in normal and $\mathrm{Ca}^{2+}$-free ACSF (see also Table 2). Neither the combination of CNQX $(30 \mu \mathrm{M})$ and APV $(200 \mu \mathrm{M})$ nor AP3 (1 mM) had any effect on ACPD-induced increases in $340 / 380$ ratios (Table 2). In comparison with the responses 
elicited by GLU and QUIS, the ( \pm )-ACPD elicited responses showed a rapid increase immediately followed by a gradual decrease even in the continued presence of ( \pm )-ACPD (Fig. $2 B$ ). When the ACPD was removed, the $340 / 380$ ratios slowly returned to basal levels.

\section{Ionotropic receptor agonists}

Figure $3 A$ shows an example of $\mathrm{K} \Lambda$ induced increases in the $340 / 380$ ratio of an NM neuron in normal ACSF. Increasing concentrations of $\mathrm{KA}$ induced progressively larger increases in $340 / 380$ ratios of NM neurons as listed in Table 3. KA concentrations greater than $50 \mu \mathrm{M}$ induced $340 / 380$ increases from which the NM neurons did not recover. $\mathrm{Ca}^{2+}$-free ACSF completely abolished the NM response to KA at any concentration (seven neurons, $n=2$ slices; data not shown). Figure $3 A$ also shows that $30 \mu \mathrm{M}$ CNQX and $200 \mu \mathrm{M}$ APV completely eliminated the $340 / 380$ increase induced by $50 \mu \mathrm{M} \mathrm{KA}$. In contrast, AP3 potentiated the $340 / 380$ increase induced by $50 \mu \mathrm{M} \mathrm{KA}$ (Fig. 3A, Table 3). KA-induced responses were similar in shape and recovery time to the GLU-induced responses, but appeared to have a slightly faster rise time.

AMPA elicited 340/380 increases from NM neurons that were almost identical in form to those elicited by KA. In normal ACSF, AMP $\Lambda$ induced $340 / 380$ increases in NM neurons as listed in Table 3. $\mathrm{Ca}^{2+}$-free ACSF completely abolished the response to $50 \mu \mathrm{M}$ AMPA in eight neurons ( $n=3$ slices).

Figure $3 B$ shows an example of NMDA-induced $340 / 380$ increases in normal ACSF. NMDA, $100 \mu \mathrm{M}$ and $250 \mu \mathrm{M}$, induced $340 / 380$ increases in NM neurons as listed in Table 3. Lower concentrations failed to elicit a response. Occasionally, $100 \mu \mathrm{M}$ NMDA did not elicit the rapidly rising response observed with the other agonists, but a more gradual increase as shown in Figure $3 B$. The response to $250 \mu \mathrm{M}$ NMDA appeared to have a biphasic rise followed by the characteristic biphasic decay to baseline. Concentrations higher than $250 \mu \mathrm{M}$ were not tested in normal ACSF. NMDA $(500 \mu \mathrm{M})$ failed to elicit an increase in $340 / 380$ ratio in $\mathrm{Ca}^{2+}$-free $\mathrm{ACSF}$ ( 37 neurons, $n=5$ slices, data not shown).

\section{Discussion}

In this study we have shown that NM neurons in an in vitro slice preparation show an increase in $\left[\mathrm{Ca}^{2+}\right]_{i}$ in response to glutamate (GLU), quisqualate (QUIS), aminocylopentane-1,3dicarboxylate (ACPD), kainate (KA), $\alpha$-amino-3-hydroxy-5methyl-isoxazole-4-propionate (AMPA) and NMDA in normal $\mathrm{Ca}^{2+}$-containing media. In addition, we have shown that NM neurons exhibit $\mathrm{Ca}^{2+}$ mobilizing responses to metabotropic glutamate receptor (mGluR) agonists that are not blocked by ionotropic glutamate receptor (iGluR) antagonists nor abolished by removal of external $\mathrm{Ca}^{2+}$. In the remainder of this report we will discuss the pharmacology of this response and then examine the possible functional significance of the mGluR-mediated response in terms of afferent regulation of NM neurons.

\section{NM neuron iGluR pharmacology}

NMDA, KA, and AMPA are all analogs of glutamate that specifically stimulate respective classes of iGluRs (Monaghan et al., 1989). In this study, all three iGluR agonists elicited responses from NM neurons in normal ACSF, but not in $\mathrm{Ca}^{2+}$-free ACSF. These responses were abolished by iGluR antagonists CNQX and APV. This is consistent with the activation of iGluRs. The concentrations of ionotropic receptor agonists used in this study to elicit $\mathrm{Ca}^{2+}$ responses are similar to concentrations used to elicit electrophysiological responses from NM neurons in slices (Zhou and Parks 1992a,b) and in whole-cell and patch-clamp configurations (Raman and Trussell, 1992).

\section{NM neuron $m G$ GR pharmacology}

$\mathrm{Ca}^{2+}$ concentrations in the cytoplasm can increase two ways: (1) influx through voltage operated $\mathrm{Ca}^{2+}$ channels (VOCCs) in the plasma membrane, or (2) release from intracellular stores. If the first alternative is eliminated by blocking receptors whose activation depolarizes the cell and opens the VOCCs, or by removing external $\mathrm{Ca}^{2+}$, any subsequent increase in $\left[\mathrm{Ca}^{2+}\right]_{i}$ in response to stimulation can be assumed to come from intracellular stores. Release of $\mathrm{Ca}^{2+}$ from intracellular stores can be elicited by a breakdown product of PI metabolism, $\mathrm{IP}_{3}$ (Nishizuka, 1984). We previously reported that GLU and ACPD, but not QUIS, stimulate an increase in $\mathrm{IP}_{3}$ levels in isolated cochlear nucleus tissue (Zirpel et al., 1994). In this study we show that GLU, QUIS, and ACPD mobilize $\mathrm{Ca}^{2+}$ in NM neurons in the presence of iGluR antagonists and in the absence of external $\mathrm{Ca}^{2+}$. This provides compelling evidence that NM neurons possess an mGluR that is linked to the PI metabolism $/ \mathrm{Ca}^{2+}$ signal transduction cascade. However, in view of our previous study, it was somewhat surprising to find that concentrations of $A C P D$ that stimulated PI metabolism failed to elicit any change in $\left[\mathrm{Ca}^{2+}\right]_{i}$, while, conversely, concentrations of QUIS that failed to elicit PI metabolism were very effective at inducing $\left[\mathrm{Ca}^{2+}\right]_{i}$ changes.

The different responses to ACPD could be due to activation of a presynaptic mGluR by ACPD (Herrero et al., 1992; Lovinger et al., 1993). It has recently been shown that mGluRs coupled to PI metabolism exist on presynaptic terminals (Adamson et al., 1990; Brammer et al., 1991) and are sensitive to ACPD (Takagi et al., 1992). The terminals of the eighth nerve that innervate NM neurons could possess a PI metabolismcoupled subtype of mGluR that is sensitive to ACPD while NM neurons express a subtype of mGluR that is much less sensitive to ACPD. Similarly, glial cells have been shown to express mGluR-mediated PI metabolism (Nicoletti et al., 1990; Jensen and Chiu, 1991). The inositol phosphates assay used in the previous study was performed on NM tissue that still contained synaptic terminals and glial cells. The presence of these terminals and glia could have elevated the ACPD-stimulated accumulation of inositol phosphates. In the present study, $\left[\mathrm{Ca}^{2+}\right]_{i}$ of the postsynaptic cell was monitored and any effect of ACPD on the presynaptic terminal or glial cells would not have been seen. It should also be noted that the concentrations of ACPD needed to elicit $\left[\mathrm{Ca}^{2+}\right]_{i}$ changes in the present study are significantly higher than concentrations reported to elicit formation of $\mathrm{IP}_{3}$ and increase $\left[\mathrm{Ca}^{2+}\right]$, in hippocampal neurons in slices and in culture (reviewed in Schoepp, 1993). This difference could be due to expression of a unique mGluR by NM neurons, a difference in tissue permeability to agonist application, or a number of other independent variables. The present study did not address this issue.

The different responses to QUIS are not as easy to resolve. There are at least two plausible explanations. First, the NM mGluR may desensitize to QUIS with different kinetics than to GLU. mGluRs coupled to PI metabolism in neuronal cultures have been shown to desensitize when preincubated with GLU or QUIS (Catania et al., 1991). In our previous study, agonist exposure times were quite long $(15 \mathrm{~min})$. Perhaps, since the NM 
mGluR appears to be most sensitive to QUIS, a long exposure to QUIS desensitized the mGluR to an extent that we were not able to detect elevated inositol phosphates. Second, since exposure times in the previous study were so long, QUIS may have caused $\mathrm{Ca}^{2+}$-induced cell death (Garthwaite and Garthwaite, 1986a,b; Choi, 1987, 1988). In the present study, $60 \mathrm{sec}$ exposures to QUIS concentrations greater than $100 \mu \mathrm{M}$ appeared to kill NM neurons.

Similarly, the concentrations of QUIS that elicited changes in $\left[\mathrm{Ca}^{2+}\right]_{i}$ in this study are considerably lower than those used by Zhou and Parks (1992b) to elicit electrophysiological responses. This difference could be due to different affinities for QUIS of mGluRs (the effects of which were monitored in this study) versus iGluRs [the effects of which were monitored by Zhou and Parks (1992b)]. Additionally, while we observed that concentrations of QUIS greater than $100 \mu \mathrm{M}$ induced increases in $\left[\mathrm{Ca}^{2+}\right]_{i}$ from which the NM neurons could not recover, Zhou and Parks (1992b) reported recovery of field potentials following exposure to QUIS concentrations greater than $500 \mu \mathrm{M}$. This discrepancy may be due to the fact that Zhou and Parks (1992b) allowed recovery to occur over the course of hours while we allowed recovery for a maximum of $15 \mathrm{~min}$. Perhaps $\left[\mathrm{Ca}^{2+}\right]_{i}$ levels would have returned to baseline had recovery been monitored for longer time periods.

Of the cloned mGluRs, the mGluR described in this study most closely resembles mGluR 1 based on signal transduction pathways and pharmacological profile. mGluRl stimulates PI metabolism $/ \mathrm{Ca}^{2+}$ liberation with a rank order of agonist potency of QUIS > GLU > ACPD (Houamed et al., 1991; Abe et al., 1992; Aramori and Nakanishi, 1992); the NM mGluR stimulates PI metabolism/ $\mathrm{Ca}^{2}$ l liberation with a rank order of agonist potency of QUIS > GLU $\gg$ ACPD. AP3 has been shown to have inhibitory effects on mGluR-stimulated PI metabolism in several types of tissue (Schoepp and Johnson, 1989; Desai and Conn, 1990; Schoepp et al., 1990; Lonart et al., 1992) and in oocytes injected with cDNA constructed from rat brain RNA (Houamed et al., 1991). However, in Chinese hamster ovary (CHO) cells expressing mGluR 1 (Aramori and Nakanishi, 1992) and mGluR5 (Abe et al., 1992), AP3 had no inhibitory effect on mGluR-stimulated PI metabolism. AP3 has no effect on NM mGluR mediated PI metabolism/ $\mathrm{Ca}^{2+}$ liberation. In addition, we have shown that mGluR agonists activate the adenylate cyclase-cAMP cascade in NM neurons (E. A. Lachica, R. Rübsamen, L. Zirpel, and E. W Rubel, unpublished observations). mGluR 1 is the only one of the six cloned mGluRs shown to stimulate adenylate cyclase (Aramori and Nakanishi, 1992).

Although it is clear that glutamate stimulated increases in $\left[\mathrm{Ca}^{2+}\right]$, in NM neurons, it is puzzling that there were two response populations with regard to concentrations. We examined whether these two populations differed in their initial response to $\mathrm{KCl}$ depolarization and found no difference in the $\left[\mathrm{Ca}^{2+}\right]_{i}$ response to $60 \mathrm{mM} \mathrm{KCl}$ between the population of slices responding to micromolar concentrations of glutamate and the population of slices responding to millimolar concentrations of glutamate. One possible explanation is based on the characterization of two forms of mGluR1 (Pickering et al., 1993). $\operatorname{mGluR} 1 \beta$ is an alternatively spliced form of $\operatorname{mGluR} l \alpha$ with a modified carboxy terminus and different sensitivity to activation by GLU. Depending upon some type of environmental or developmental condition, NM neurons may express one variant or the other as a population within a slice. Using whole-cell and outside-out patch clamp techniques on NM neurons, Raman and Trussell (1992) showed that small currents could be elicited with $100 \mu \mathrm{M}$ GLU and increasing concentrations of GLU, up to $10 \mathrm{~mm}$, produced increasingly larger peak currents. By examining the effects of bath-applied agonists on the postsynaptic NM neuron response to cochlear nerve stimulation, Zhou and Parks (1992b) have shown that the concentration of GLU needed to produce half - maximal inhibition of the response is 18 mM. Thesc data, in conjunction with our observation that there was no reliable difference in magnitude of responses to micromolar concentrations of GLU in normal and $\mathrm{Ca}^{2+}$-free ACSF, suggest that the responses we observed to millimolar concentrations of GLU might be more "normal" than the responses to micromolar concentrations.

\section{Functional significance}

Changes in intracellular calcium concentrations have been implicated in cell death in a number of situations (Choi, 1988; Siesjo, 1988). In fact, $\left[\mathrm{Ca}^{2+}\right]_{i}$ homeostasis within a relatively narrow range is critical for neuron viability (Koike et al., 1989; Carafoli, 1991; Collins et al., 1991; Franklin and Johnson, 1992). It is therefore plausible that regulation of $\left[\mathrm{Ca}^{2+}\right]_{i}$ of $\mathrm{NM}$ neurons is a critical factor in the trophic interaction between eighth nerve activity and NM neurons. A metabotropic glutamate receptor that is coupled to a signal transduction system directly affecting $\left[\mathrm{Ca}^{2+}\right]_{i}$, as well as various protein kinases is an excellent candidate for mediator of this transneuronal regulation.

Metabotropic glutamate receptors coupled to PI metabolism generate inositol-1,4,5-trisphosphate ( $\mathrm{IP}_{3}$ ) and diacylglycerol (DAG), which liberate $\mathrm{Ca}^{2+}$ from intracellular stores and activate protein kinase C $(\mathrm{PKC})$, respectively (Nishizuka, 1984, 1986). Increasing adenylate cyclase activity via activation of an mGluR, leads to an increase in cAMP levels (Tanabe et al., 1992; Winder and Conn, 1992) and a subsequent increase in protein kinase A (PKA) activity. Therefore, activation of an mGluR linked to both PI metabolism and adenylate cyclase activity, such as the NM mGluR, imparts to the innervating terminal the ability to affect not only $\mathrm{Ca}^{2+}$ levels and any $\mathrm{Ca}^{2+}$ dependent enzymes present in the postsynaptic cell, but also the activities of PKA and PKC. Effects of PKA and PKC activity in neurons include modulation of ionotropic glutamate receptors (Greengard et al., 1991; Wang et al., 1991; Bleakman et al., 1992; Cerne and Randic, 1992; Glaum and Miller, 1993; Kinney and Slater, 1993); modulation of voltage-gated $\mathrm{Ca}^{2+}$ channels (Lester and Jahr, 1990; Sayer et al., 1992; Swartz and Bean, 1992; Sahara and Westbrook, 1993; Swartz et al., 1993), and modulation of c-fos transcription (Sheng et al., 1990). Activation of metabotropic glutamate receptors even regulates expression of mGluR mRNA in cultured cerebellar neurons (Bessho et al., 1993) and cell proliferation in astrocytes (Condorelli et al., 1989). Thus, via the NM mGluR, eighth nerve activity could have the ability to regulate $\mathrm{NM}$ neuron excitability, $\mathrm{Ca}^{2+}$ influx across the plasma membrane, gene expression and perhaps a myriad of other yet uncharacterized cellular functions that are modulated by protein phosphorylation. It is therefore easy to imagine how the NM neurons could be dependent upon this input for maintenance and survival. Experiments combining stimulation of the eighth nerve with pharmacological manipulation of mGluR activity are addressing this hypothesis.

\section{References}

Abe T, Sugihara H, Nawa H, Shigemoto R, Mizuno N, Nakanishi S (1992) Molecular characterization of a novel metabotropic glutamate 
receptor mGluR5 coupled to inositol phosphate/ $\mathrm{Ca}^{2+}$ signal transduction. J Biol Chem 267:13361-13368.

Adamson P, Hajimohammadreza I, Brammer MJ, Campbell IC, Meldru BS (1990) Presynaptic glutamate/quisqualate receptors: effects on synaptosomal free calcium concentrations. J Neurochem 55:18501854.

Aramori I, Nakanishi S (1992) Signal transduction and pharmacological characteristics of a metabotropic glutamate receptor, mGluR 1 in transfected CHO cells. Neuron 8:757-765.

Bessho Y, Nawa H, Nakanishi S (1993) Glutamate and quisqualate regulate the expression of metabotropic glutamate receptor mRNA in cultured cerebellar granule cells. J Neurochem 60:253-259.

Bleakman D, Rusin KI, Chard PS, Glaum SR, Miller RJ (1992) Metabotropic glutamate receptors potentiate ionotropic glutamate responses in the rat dorsal horn. Mol Pharmacol 42:192-196.

Born DE, Rubel EW (1985) Afferent influences on brain stem auditory nuclei of the chicken: neuron number and size following cochlea removal. J Comp Neurol 231:435-445.

Born DE, Rubel EW (1988) Afferent influences on brain stem auditory nuclei of the chicken: presynaptic action potentials regulate protein synthesis in nucleus magnocellularis neurons. J Neurosci 8:901-919.

Brammer MJ, Richmond S, Xiang JZ, Adamson P, Hajimohammadreza I, Silva MA, Campbell IC (1991) Kainate and quisqualate effects on rat presynaptic cortical receptors are metabotropic and nonadditive. Neurosci Lett 128:231-234.

Carafoli E (1991) Calcium pump of the plasma membrane. Physiol Rev 71:129-153.

Cartmell J, Kemp JA, Alexander SPH, Hill SJ, Kendall DA (1992) Inhibition of forskolin-stimulated cyclic AMP formation by 1-aminocyclopentane-trans-1,3-dicarboxylate in guinea-pig cerebral cortical slices. J Neurochem 58:1964-1966.

Catania MV, Aronica E, Sortino MA, Canonico PL, Nicoletti F (1991) Desensitization of metabotropic glutamate receptors in neuronal cultures. J Neurochem 56:1329-1335.

Cerne R, Randic M (1992) Modulation of AMPA and NMDA responses in rat dorsal horn neurons by trans-1-aminocyclopentane1,3-dicarboxylic acid. Neurosci Lett 144:180-184.

Choi DW (1987) Ionic dependence of glutamate neurotoxicity. J Neurosci 7:369-379.

Choi DW (1988) Glutamate neurotoxicity and diseases of the nervous system. Neuron 1:623-634.

Collins F, Schmidt MF, Guthrie PB, Kater SB (1991) Sustained increase in intracellular calcium promotes neuronal survival. J Neurosci 11:2582-2587.

Condorelli DF, Ingrao F, Magri G, Bruno V, Nicoletti F, Avola R (1989) Activation of excitatory amino acid receptors reduces thymidine incorporation and cell proliferation rate in primary cultures of astrocytes. Glia 2:67-69.

Desai MA, Conn PJ (1990) Selective activation of phosphoinositide hydrolysis by a rigid analogue of glutamate. Neurosci Lett 109:157162.

Franklin JL, Johnson EM Jr (1992) Suppression of programmed neuronal death by sustained elevation of cytoplasmic calcium. Trends Neurosci 15:501-508.

Garthwaite G, Garthwaite J (1986a) In vitroneurotoxicity of excitatory acid analogues during cerebellar development. Neuroscience 17:755767.

Garthwaite G, Garthwaite J (1986b) Neurotoxicity of excitatory amino acid receptor agonists in rat cerebellar slices: dependence on calcium concentration. Neurosci Lett 66:193-198.

Glaum SR, Miller RJ (1993) Activation of metabotropic glutamate receptors produces reciprocal regulation of ionotropic glutamate and GABA responses in the nucleus of the tractus solitarius of the rat. $J$ Neurosci 13:1636-1641.

Greengard P, Jen J, Nairn AC, Stevens CF (1991) Enhancement of the glutamate response by cAMP-dependent protein kinase in hippocampal neurons. Science 253:1135-1138.

Grynkiewicz G, Poenie M, Tsien RY (1985) A new generation of $\mathrm{Ca}^{2+}$ indicators with greatly improved fluorescence properties. J Biol Chem 260:3440-3450.

Herrero I, Miras-Portugal MT, Sanchez-Prieto J (1992) Positive feedback of glutamate exocytosis by metabotropic presynaptic receptor stimulation. Nature 360:163-166.

Houamed KM, Kuijper JK, Gilbert TL, Haldeman BA, O'Hara PJ, Mulvihill ER, Almers W, Hagen FS (1991) Cloning, expression and gene structure of a $\mathrm{G}$ protein-coupled glutamate receptor from rat brain. Science 252:1318-1321.

Hyson RL, Rubel EW (1989) Transneuronal regulation of protein synthesis in the brain stem auditory system of the chick requires synaptic activation. J Neurosci 9:2835-2845.

Irving AJ, Schofield JG, Watkins JC, Sunter DC, Collinridge GL (1990) $1 S, 3 R$-ACPD stimulates and $\mathrm{L}-\mathrm{AP} 3$ blocks $\mathrm{Ca}^{2+}$ mobilization in rat cerebellar neurons. Eur J Pharmacol 186:363-368.

Jackson H, Nemeth EF, Parks TN (1985) Non- $N$-methyl-D-aspartate receptors mediating synaptic transmission in the avian cochlear nucleus: effects of kynurenic acid, dipicolinic acid and streptomycin. Neuroscience 16:171-179.

Jensen AM, Chiu SY (1991) Differential intracellular calcium responses to glutamate in type 1 and type 2 cultured brain astrocytes. J Neurosci 11:1674-1684.

Kinney GA, Slater NT (1993) Potentiation of NMDA receptor-mediated transmission in turtle cerebellar granule cells by activation of metabotropic glutamate receptors. J Neurophysiol 69:585-594.

Koike T, Martin DP, Johnson EM Jr (1989) Role of $\mathrm{Ca}^{2+}$ channels in the ability of membrane depolarization to prevent neuronal death induced by trophic-factor deprivation: evidence that levels of internal $\mathrm{Ca}^{2+}$ determine nerve growth factor dependence of sympathetic ganglion cells. Proc Natl Acad Sci USA 86:6421-6425.

Lester RAJ, Jahr CE (1990) Quisqualate receptor-mediated depression of calcium currents in hippocampal neurons. Neuron 4:741-749.

Lonart G, Alagarsamy S, Ravula R, Wang J, Johnson KM (1992) Inhibition of phospholipase C-linked metabotropic glutamate receptor by 2-amino-3-phosphonopropionate is dependent on extracellular calcium. J Neurochem 59:772-775.

Lovinger DM, Tyler E, Fidler S, Merritt A (1993) Properties of a presynaptic metabotropic glutamate receptor in rat neostriatal slices. J Neurophysiol 69:1236-1244.

Manzoni O, Fagni L, Pin J-P, Rassendren F, Poulat F, Sladeczek F, Bockaert J (1990) (trans)-1-amino-cyclopentyl-1,3-dicarboxylate stimulates quisqualate phosphoinositide-coupled receptors but not ionotropic glutamate receptors in striatal neurons and Xenopus oocytes. Mol Pharmacol 38:1-6.

Martin M (1985) Excitatory amino acid pharmacology of the auditory nerve and nucleus magnocellularis of the chicken. Hearing Res 17: $153-160$.

Masu M, Tanabe Y, Tsuchida K, Shigemoto R, Nakanishi S (1991) Sequence and expression of a metabotropic glutamate receptor. $\mathrm{Na}$ ture 349:760-765.

Monaghan DT, Bridges RJ, Cotman CW (1989) The excitatory amino acid receptors: their classes, pharmacology and distinct properties in the function of the central nervous system. Annu Rev Pharmacol Toxicol 29:365-402.

Nakajima Y, Iwakabe H, Akazawa C, Nawa H, Shigemoto R, Mizuno $\mathrm{N}$, Nakanishi S (1993) Molecular characterization of a novel retinal metabotropic glutamate receptor mGluR6 with a high agonist selectivity for L-2-amino-4-phosphonobutyrate. J Biol Chem 268:1186811873.

Nemeth EF, Jackson H, Parks TN (1983) Pharmacological evidence for synaptic transmission mediated by non- $N$-methyl-D-aspartate receptors in the avian cochlear nucleus. Neurosci Lett 40:39-44.

Nicoletti F, Magri G, Ingrao F, Bruno V, Catania MV, Dell'Albani P, Condorelli DF, Avola R (1990) Excitatory amino acids stimulate inositol phospholipid hydrolysis and reduce proliferation in cultured astrocytes. J Neurochem 54:771-777.

Nishizuka $Y$ (1984) The role of protein kinase $C$ in cell surface transduction and tumor promotion. Nature 308:691-698.

Nishizuka Y (1986) Studies and perspectives of protein kinase C. Science 233:305-311.

Pickering DS, Thomsen C, Suzdak PD, Fletcher EJ, Robitaille R, Salter MW, MacDonald JF, Huang X-P, Hampson DR (1993) A comparison of two alternatively spliced forms of a metabotropic glutamate receptor coupled to phosphoinositide turnover. J Neurochem 61:8592.

Raman IM, Trussell LO (1992) The kinetics of the response to glutamate and kainate in neurons of the avian cochlear nucleus. Neuron 9:173-186.

Rubel EW, Hyson RL, Durham D (1990) Afferent regulation of neurons in the brain stem auditory system. J Neurobiol 21:169-196.

Sahara Y, Westbrook GL (1993) Modulation of calcium currents by a metabotropic glutamate receptor involves fast and slow kinetic 
components in cultured hippocampal neurons. J Neurosci 13:30413050 .

Sayer RJ, Schwindt PC, Crill WE (1992) Metabotropic glutamate receptor-mediated suppression of L-type calcium current in acutely isolated neocortical neurons. J Neurophysiol 68:833-842.

Schoepp DD (1993) The biochemical pharmacology of metabotropic glutamate receptors. Biochem Soc Trans 21:97-102.

Schoepp DD, Johnson BG (1989) Inhibition of excitatory amino acidstimulated phosphoinositide hydrolysis in the neonatal rat hippocampus by 2-amino-3-phosphonopropionate. J Neurochem 53:1865-1870.

Schoepp D, Bockaert J, Sladeczek F (1990) Pharmacological and functional characteristics of metabotropic excitatory amino acid receptors. Trends Pharmacol Sci 11:508-515.

Schoepp DD, Johnson BG, Salhoff CR, McDonald JW, Johnston MV (1991) In vitro and in vivo pharmacology of trans- and cis-( \pm )-1amino-1,3-cyclopentanedicarboxylic acid: dissociation of metabotropic and ionotropic excitatory amino acid receptor effects. J Neurochem 56:1789-1796.

Schoepp DD, Johnson BG, Monn JA (1992) Inhibition of cyclic AMP formation by a selective metabotropic glutamate receptor agonist. J Neurochem 58:1184-1186.

Sheng M, McFadden G, Greenberg ME (1990) Membrane depolarization and calcium induce $c$-fos transcription via phosphorylation of transcription factor CREB. Neuron 4:255-268.

Siesjo BK (1988) Calcium, ischemia and death of brain cells. Ann NY Acad Sci 522:638-661.

Sugiyama H, Ito I, Hirono C (1987) A New type of glutamate receptor linked to inositol phospholipid metabolism. Nature 325:531-533.

Swartz KJ, Bean BP (1992) Inhibition of calcium channels in rat CA3 pyramidal neurons by a metabotropic glutamate receptor. J Neurosci 12:4358-4371.
Swartz KJ, Merritt A, Bean BP, Lovinger DM (1993) Protein kinase $C$ modulates glutamate receptor inhibition of $\mathrm{Ca}^{2+}$ channels and synaptic transmission. Nature 361:165-168.

Takagi H, Takimizu H, Barry Jd, Kudo Y, Yoshioka T (1992) The expression of presynaptic $t$-ACPD receptor in rat cerebellum. Biochem Biophys Res Commun 189:2187-1295.

Tanabe Y, Masu M, Isii T, Shigemoto R, Nakanishi S (1992) A family of metabotropic glutamate receptors. Neuron 8:169-179.

Tanabe Y, Nomura A, Masu M, Shigemoto R, Mizuno N, Nakanishi $S$ (1993) Signal transduction, pharmacological properties and expression patterns of two rat metabotropic glutamate receptors, mGluR3 and mGluR4. J Neurosci 13:1372-1378.

Wang L-Y, Salter MW, MacDonald JF (1991) Regulation of kainate receptors by cAMP-dependent protein kinase and phosphatases. Science 253:1 132-1135.

Winder DG, Conn PJ (1992) Activation of metabotropic glutamate receptors in the hippocampus increases cyclic AMP accumulation. $J$ Neurochem 59:375-378.

Zhou N, Parks TN (1992a) Developmental changes in the effects of drugs acting at NMDA or non-NMDA receptors on synaptic transmission in the chick cochlear nucleus (nuc. magnocellularis). Dev Brain Res 67:145-152.

Zhou N, Parks TN (1992b) $\gamma$-D-Glutamylaminomethyl sulfonic acid (GAMS) distinguishes subtypes of glutamate receptor in the chick cochlear nucleus (nuc. magnocellularis). Hearing Res 60:20-26.

Zirpel L, Rubel EW (1993) Glutamate stimulated changes in intracellular calcium in neurons of the avian cochlear nucleus. Soc Neurosci Abstr 19:534.

Zirpel L, Nathanson NM, Rubel EW, Hyson RL (1994) Glutamate stimulated phosphatidylinositol metabolism in the avian cochlear nucleus. Neurosci Lett 168:163-166 